\title{
Vygotsky in English: What Still Needs to Be Done
}

\author{
René van der Veer • Anton Yasnitsky
}

Published online: 28 May 2011

(C) The Author(s) 2011. This article is published with open access at Springerlink.com

\begin{abstract}
At present readers of English have still limited access to Vygotsky's writings. Existing translations are marred by mistakes and outright falsifications. Analyses of Vygotsky's work tend to downplay the collaborative and experimental nature of his research. Several suggestions are made to improve this situation. New translations are certainly needed and new analyses should pay attention to the contextual nature of Vygotsky's thinking and research practice.
\end{abstract}

Keywords Vygotsky $\cdot$ Translations $\cdot$ Research networks $\cdot$ History of psychology Censorship

\section{Introduction}

The international interest in the ideas of the Russian psychologist Lev Vygotsky (1896-1934) is still growing. The number of publications about this seminal historical figure is growing almost exponentially. English being the modern language of scientific discourse (whether we like it or not), many of the researchers interested in Vygotsky's thinking make use of translations available in English. This makes it especially important that the English translations of Vygotsky's writings are reliable and present an adequate picture of all his ideas. It is only on the basis of an accurate corpus of all of his publications that we can arrive at an adequate assessment and subsequent elaboration or criticism of Vygotsky's work.

In what follows we shall give a brief and incomplete characterization of the currently available translations and indicate several problems that still have to be solved. We shall

This paper is an elaborated and revised version of a paper by the first author that has been available on the internet.

R. van der Veer $(\bowtie)$

Leiden University, Leiden, Netherlands

e-mail: veer@fsw.LeidenUniv.nl

A. Yasnitsky

York University, Toronto, ON, Canada 
conclude with a proposal how to solve these problems. But first an overview of what has been translated and what yet remains to be translated into English will be presented.

\section{What We Have}

In the discussion of what is presently available in the English language we will restrict ourselves to book publications. Various articles and chapters by Vygotsky and his coworkers have been available in English since the 1920s when they were first published but these went virtually unnoticed and Vygotsky became only known to a larger public with the first publication by the MIT Press of Thought and Language (Vygotsky 1962). This book still remains Vygotsky's best known work. The second of Vygotsky's books to see the light in the Anglo-Saxon world was The Psychology of Art (Vygotsky 1971), a book that because of its subject matter is far less popular among general psychologists. These early translations were followed by a book that subsequently would become immensely popular, namely Mind in Society (Vygotsky 1978). Mind in Society and other books paved the way for the retranslation, after almost 25 years, of Thought and Language (Vygotsky 1986). Yet another translation of Thought and Language appeared one year later as the first volume of the Plenum edition of Vygotsky's Collected Works (Rieber and Carton 1987), a translation of six volumes that had appeared in the Soviet Union in the 1980s. The next five volumes of the Plenum edition appeared with considerable delay in the 1990s (Rieber 1997, 1998, 1999; Rieber and Carton 1993; Rieber and Wollock 1997). In between, we saw the appearance of two translations (under different titles) of Ape, primitive, and child (Vygotsky 1992, 1993), a volume of translated articles and chapters (Van der Veer and Valsiner 1994), and Educational Psychology (1997).

Together, these books present a fairly good (although not accurate, as we will see) picture of the work of Vygotsky the psychologist but it would be an illusion to think that they are in any way exhaustive. That is, although on the basis of the existing translations in English one can form a reasonable idea of what Vygotsky's main ideas were, there remain still large gaps in the translation record. If we were to publish an edition of Vygotsky's Complete Works rather than his Collected Works, at least the books mentioned in the next paragraph should be included.

\section{What is Missing}

In listing what has not yet been translated we will again largely restrict ourselves to book publications (cf. the bibliographies in Mangott 1995, and Vygodskaya and Lifanova 1996). Space would not allow an enumeration of the numerous articles and chapters and a brief discussion of books yet to be translated will illustrate the point just as well.

It is important to know that several of Vygotsky's books were meant as textbooks for students' use in higher education. To these books belong the three volumes of Pedology of the Adolescent published in 1929, 1930, and 1931. Although some chapters of these textbooks have been published in the Collected Works their full content and general character remain unknown to the English readership. To give an idea: each chapter was followed by an assignment for the students, e.g. the suggestion 
to make a summary of the chapter or to read additional literature. In about the same period, Vygotsky wrote Imagination and Creativity in Childhood (1930), a book that discussed, among other things, the development of children's drawings. In addition, with Varshava he published a Psychological Dictionary (1931), which in the style of Baldwin's and other dictionaries provided a lengthy list of concise descriptions of psychological concepts and currents. Reading such dictionaries is still interesting because they provide an intimate view of the state of art in psychology in that historical period and thus allow us to better understand its contemporary proponents. Finally, after Vygotsky's death in 1934 and on the basis of shorthand reports two more books appeared under his name. These were the volumes Children's Mental Development in the Process of Instruction (1935) and Foundations of Pedology (1935). Both provide an insight in Vygotsky's thinking in the final period of his life when he developed, among other things, the concepts of the zone of proximal development. Neither of the books have been fully translated. Fragments of several chapters of Children's Mental Development in the Process of Instruction found their way into Mind in Society (Vygotsky 1978) and one chapter of Foundations of Pedology appeared in the Vygotsky Reader (Van der Veer and Valsiner 1994). If we add to this that The Psychology of Art (Vygotsky 1971) does not contain Vygotsky's major study of Shakespeare's Hamlet (see Van der Veer and Valsiner 1991), then it will become clear that readers of English who wish to familiarize themselves with Vygotsky's theory on the basis of his own writings are still not in an ideal position.

But the situation is actually worse. Above restriction was made to books and to publications that focused on psychology or related disciplines. However, it is well known that Vygotsky began his intellectual career in the 1910s and early 1920s in the domain of the fine arts writing countless reviews of theater performances, novels, and so on. So far, more than 90 of these reviews have been identified but to my knowledge few have been translated into any language. It would of course be highly relevant for our assessment of Vygotsky the non-psychologist to have these articles gathered, translated, and annotated.

Finally, the hypothetical Complete Works mentioned above would also include, apart from the numerous articles, encyclopedia papers, chapters, etc., Vygotsky's correspondence, private notes, and poems.

In sum, it is my estimation that one might easily add 6 more volumes to the existing translations in English. These volumes would partially confirm what we already know about Vygotsky, but would also partially complete and possibly redress our picture of his creative work. That brings me to the quality of that which is available in translation.

\section{Sources of Error}

It is important to realize that in translating a historical author there are multiple sources of error and that in the case of Vygotsky the situation was aggravated for ideological or political reasons. Existing translations are sometimes based on Soviet editions that were unreliable and added their own mistakes. The potential sources of error or distortion can be illustrated as follows (see Fig. 1)

As one can see in Fig. 1, there are multiple sources of error. First, a book publication may be based on a manuscript or published articles or a mixture of both. Second, this 
Fig. 1 Sources of error in Vygotsky's work

articles manuscripts

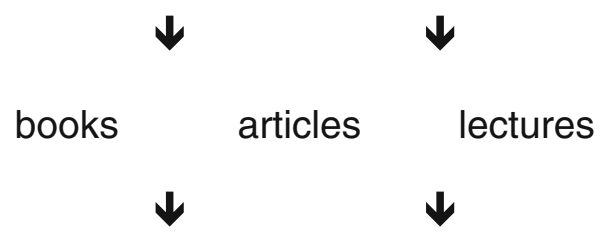

(several) Soviet editions

\section{English translations}

book may be republished one or more times. Third, the book is translated into English. All these transitions from one form to another are potential sources of error. In case something goes wrong in the transition from manuscript to book we are mostly helpless, because manuscripts may no longer exist or be accessible. Also, it will be difficult to assess whether changes in the text were part of the normal editorial process or introduced without consent of the author. However, when books are based on earlier publications we have in principle a possibility of judging the reliability of the book's text. That is, although the transition from published article to a book volume forms a potential source of error, it at the same time gives us a means to check the reliability of the final product.

\section{The Case of Thinking and Speech ('Thinking and Speech')}

The case of Vygotsky's Thinking and speech (1934) illustrates this state of affairs rather well (see Table 1).

Table 1 The composition of Vygotsky's thinking and speech

\begin{tabular}{llll}
\hline Text & pages & date of writing & source \\
\hline Preface & $1-3$ & Spring 1934 & \\
Chapter 1 & $4-15$ & Spring 1934 & \\
Chapter 2 & $16-66$ & before 1932 & Vygotsky (1932) \\
Chapter 3 & $67-75$ & before 1929 & Vygotsky (1929a) \\
Chapter 4 & $76-102$ & before 1929 & Vygotsky (1929b) \\
Chapter 5 & $103-162$ & before 1931 & Vygotsky (1931) \\
Chapter 6 & $163-176$ & February 1934 & Shif (1935) \\
& $177-255$ & Spring 1934 & Shif (1935) \\
Chapter 7 & $256-259$ & February 1934 & \\
\hline
\end{tabular}


First, as we can see this book was partially based on articles that Vygotsky published earlier. Using these original articles from the 1920s and the early 1930s, several changes ('errors') have been detected in the 1934 edition. Second, Thinking and speech was republished in Russian in 1956 and 1982. As Mecacci has documented in his comments in Vygotsky (1990), there are numerous differences between the three Russian editions of Vygotsky's book. A full list of the literally hundreds of sometimes incomprehensible differences between the editions of 1934, 1956, and 1982 has not yet been published, but it would clearly and redundantly show that the later versions are corrupted and unfit to serve as the source for translation into English. Yet, this is precisely what happened with the American translation for the Plenum edition (Rieber and Carton 1987). As a result, this translation not only contains gross mistakes introduced by the translator but also numerous changes introduced in the series of Soviet editions. The net result is a useless text. The proper thing to do would have been, of course, to take the 1934 edition as the basis of translation and to note any discrepancies with the earlier articles that are at the root of the book.

\section{Types of Error}

To illustrate what was said above, a number of examples of errors in the English translations of Vygotsky's texts will now be given. These errors were detected over the years by a number of researchers using the means indicated above, that is, comparing publications with the original articles, manuscripts, or books wherever that proved possible. These authors include Brushlinsky (1996), Etkind (1993), Tkachenko (1983), Tulviste (1987), Van der Veer (1987, 1998), and Van der Veer and Valsiner (1991). Many of the inadequacies of the English translations go back to inadequacies of the Soviet editions but translators inevitably added their own share. For clarity's sake, these errors have been divided into a number of subcategories.

\section{Inaccuracies}

Under the heading of 'inaccuracies' are included all those changes of the original texts that were unintended or intended with the idea of "clarifying" Vygotsky's' ideas or making him more palatable to contemporary taste. As such they differ from deliberate attempts to falsify the texts as discussed below, although the difference is sometimes small (e.g., the case of Kolbanovsky). As examples of inaccurate efforts to present Vygotsky's texts, we would first like to mention the abridged versions of Thinking and speech (Vygotsky 1962, 1986) and the compilation of texts in Vygotsky (1978).

That Vygotsky (1962) is unacceptable as a translation has been observed by many and hardly needs arguing. Suffice it to say that the whole book contains a meager 168 pages as compared to the 324 pages of the original. However, as has been argued before (Van der Veer 1987), also Vygotsky (1986) is unacceptable. As a whole, the 1986 translation of Thinking and speech is incomparably better and much more complete than the 1962 edition, yet the translator has "departed from Vygotsky's text when it repeats itself" and retained large parts of the 1962 translation. The result is that the book still contains many errors and that various 
phrases and passages have not been translated. Vygotsky's quote on the final page of his book from The German Ideology, for example, has been left unidentified and is rendered very incomplete (cf. Van der Veer 1987). Thus, we argue that both translations (Vygotsky 1962, 1986) are abridged and as such unfit for genuine scientific study.

We know of only one Vygotsky edition that qualifies as a compilation and that is Mind in Society (Vygotsky 1978). This book has enjoyed immense popularity among psychologists interested in cultural-historical theory and it served a very positive role in introducing American readers to Vygotsky's thinking. However, from a historical point of view, it is a very unsatisfactory book. As the editors explained in their preface, they have "summarized" major theoretical points, and they have "inserted material from additional sources" (including texts by Vygotsky's students or collaborators). However, on the basis of the editors' explanation, it proved impossible to identify the historical texts that lie at the basis of the final result. In sum, the editors merged in unknown ways several texts by Vygotsky and his collaborators into a coherent and easy to grasp whole. To consider the resulting text as Vygotsky's text would be incorrect. Mind in Society thus violates the principle that states that texts of historical authors should be translated in their entirety or, if only excerpts are published, that it should be clearly indicated which parts are left out, where the author's text ends and the text of others begins, and so on.

Under the heading of inaccuracies, we would further like to discuss the need for accurate annotations of the translated texts. Here there is no shortage of examples. With the exception of volume 3, the Plenum edition is very poorly annotated. Authors are left unidentified, citations are not traced to the original source, scientific terms that have gone out fashion are not explained, et cetera. Of course, authoritative translations of historical texts become much more useful if they are properly annotated. That the writing of such notes requires a considerable amount of work and historical knowledge should not prevent us from trying to reach the level of work reached in, say, the standard edition of Freud's writings.

Finally, added to abridged versions, compilations, and inadequate annotations, there are simple translation errors of words, passages, and names. Here again it is impossible to be exhaustive and one can only give some examples. A particularly intruiging example of a bad translation can be found in volume 1 of the Plenum edition (Rieber \& Carton, p. 284). There Vygotsky quoted the famous Russian poet Gumilyov's poem The Word: "And like bees in a deserted hive badly smell dead words". However, the translator rendered them as "And as the bees which have sunk into their silent Yule season so do dead words sink". This translation is not even remotely similar to the original, of course. And many more of such gross errors can be found in the Plenum edition (e.g., see the still far from complete list of errata in volume 5).

An incomplete list of inadequately transliterated names one finds in Table 2 (see Table 2).

These inaccurate names can be understood if we realize that Russian uses a phonetic system to render foreign names. However, even cursory consultation of historical psychology books, encyclopedias, and so on, would have prevented these ludicrous mistakes.

The abridged versions, compilations, and inaccurate translations mentioned above were made with the best of intentions. However, many of the existing English 
Table 2 Examples of inaccurate names in the Plenum edition

\begin{tabular}{ll}
\hline given & correct \\
\hline Fasler & Vossler \\
Faininger & Vaihinger \\
Shvabskii & Von Schwaben \\
Kompeire & Compayré \\
Charceau & Charcot \\
Zelts & Seltz \\
Gettser & Hetzer \\
Ronget & Ronjat \\
Zigvart & Sigwart \\
\hline
\end{tabular}

translations are based on Soviet editions of Vygotsky's works that are unreliable for very different reasons.

\section{Suppression of Terms or Passages}

The problem is that all of Vygotsky's works were published in the Soviet Union where books were subjected to censorship as a matter of routine. The early and later editors of Vygotsky's books were all acutely aware of this system and in their efforts to get Vygotsky's books published they often preventively adjusted his texts.

In this respect, the first editor of Thinking and speech (1934), Kolbanovsky, probably formed no exception. Elsewhere (Van der Veer and Valsiner 1991, pp. 256258), it has been argued that Kolbanovsky may have erased all references to the discipline of paedology, which by that time had come under attack. Thus Kolbanovsky persuaded Vygotsky to give his book the subtitle Psychological Investigations and probably replaced the terms "school paedology" and "paedological" by, respectively, "child psychology" and "psychological" in chapter 6. In later Soviet editions the subtitle was lost.

In the 1956 and 1982 Soviet editions of Thinking and speech we can also witness the suppression of unwelcome passages. Thus, in chapter 1 a lengthy reference to and a (not fully exact) quote from Sapir's Language (1934, p. 12) have been omitted:

In the plane of instinctive consciousness, where perception and affect reign, only contamination is possible, but not understanding and not communication in the proper sense of this word. E. Sapir beautifully explained this in his works on the psychology of speech. "Elementary language, he says, must be connected with a whole group, with a specific class of our experience. The world of experience must be extremely simplified and generalized in order to be symbolized. Only in this way communication becomes possible for singular experience lives in a singular consciousness and cannot strictly speaking be communicated. In order to become communicable it must be put in a certain class which by tacit consensus is considered as a unit by the society". That is why Sapir considers word meaning not as a symbol of singular perception but as a symbol of a concept. (to be inserted on p. 49 of volume 1 of the Plenum edition after "in a generalized way") 
We can only speculate why this passage was removed. Perhaps it was an attempt to make Vygotsky seem more original in the field of linguistics or positively mentioning the name of the 'bourgeois' researcher Sapir had become unacceptable.

In chapter 2, on the very first page of Vygotsky's discussion of Piaget's theory, a quite substantial passage containing a citation from Piaget has been removed. The quote from Piaget was as follows:

We thus believe that the day will come when the thinking of the child with respect to the adult, normal and civilized thinking, will be placed at the same level as the "primitive mentality" defined by Lévy-Bruhl, as the autistic and symbolic thinking described by Freud and his followers, and as the "morbid consciousness" assuming that this concept that we owe to Blondel will not one day merge with the preceding one (translation by the present authors from the 1924 French edition of Piaget's Judgement and Reasoning in the Child).

Vygotsky then continued in a passage approximately twice as long as the quote from Piaget by saying that the significance of Piaget's books is indeed of the same order as those of Blondel, Lévy-Bruhl, and Freud, and that these authors are by their philosophical nature intimately connected (the whole passage including the quote from Piaget should be inserted on p. 53 of volume 1 of the Plenum edition after "this old problem").

Finally, in chapter 5 of Thinking and speech, a passage has been removed that ran as follows:

and the daily change in different forms of behavior, as has been beautifully pointed out by P.P. Blonsky, essentially repeats the millennia old history of the development of behavior (to be inserted in paragraph 18, p. 160 of volume 1 of the Plenum edition, after "the most ancient").

This passage was most probably removed because it suggested that Vygotsky agreed with some version of the recapitulation thesis, a thesis that had become unacceptable in the Soviet Union by then.

This is by no means a complete list of passages that were removed in later Soviet editions but it suffices to make the point that translations based upon them, such as Rieber \& Carton (1987), are highly unreliable.

However, the problem of suppressed terms of passages is not restricted to Thinking and speech, nor to the Plenum edition. Thus, in volume 3 of the Plenum edition, on the penultimate page of The Historical Meaning of the Crisis in Psychology: A Methodological Investigation (p. 342), it is said that "The new society will create the new man". This seems a rather plausible sentence, but Tkachenko (1983) has claimed that the original manuscript of The Crisis contained the phrase "The new society will create a superman". The term 'superman' has, of course, acquired a rather negative connotation after the Nazi period, which may have been the reason why Soviet editors replaced this term (but see below).

Volume 2 of the Plenum edition (Rieber and Carton 1993) is not free from problems either. It has been shown, using the original chapter from 1928, that the chapter "The dynamics of child character" originally contained two positive pages 
and three positive passages about Alfred Adler that have been removed in subsequent Soviet editions of his work (Brushlinsky 1996). The passages were as follows:

Adler's theory is often connected-especially in circles of German and Austrian social-democrats - with Marx's theory (to be inserted on p. 162 of volume 2 of the Plenum edition)

A. Adler's theory, in particular his theory about character is "a truly revolutionary characterological current", as A. Zalkind rightly points out (to be inserted in paragraph 2 of the same chapter)

None of the contemporary psychological ideas has such enormous significance for pedagogues, for the theory and practice of education, as this idea of Adler (to be inserted in paragraph 5 of the same chapter).

These passages show Vygotsky referring positively to Adler's ideas, which was to be expected in that period of his career. Elsewhere (Van der Veer and Valsiner 1991) it was shown that Vygotsky went through a period with deep enthusiasm for Adlerian theory. Again, we can only guess why these passages were removed. The fact that Adler was a 'bourgeois', the fact that he was a former psychoanalytic theorist, the fact that 'social-democrats' linked his work to Marx, the fact that Vygotsky called his theory 'revolutionary' (whereas only Russian Marxist ideas could be truly revolutionary), and an attempt to make Vygotsky seem more original, may all have played a role (cf. Van der Veer 2000).

Vygotsky's Educational Psychology (1997) is likewise marred by suppressed passages. Elsewhere, it was shown that, among other things, three lines of a Blonsky quote on p. 4, 23 lines of a Sherrington quote on p. 35, and 60 lines on p. 335 were omitted in the English translation (Van der Veer 1998).

Again, this list of suppressed terms and passages is far from exhaustive but the point has been made. English translations of Soviet re-editions of Vygotsky's work are liable to suppressions of substantial passages of the original text.

\section{Suppression of Names}

It will come as no surprise that author names as well have disappeared in Soviet republications of Vygotsky's work and its translations into English. Kolbanovsky may have been the first to use this method: In chapter 5 of the 1934 edition of Thinking and speech the German psychologist Felix Krueger (cf. Valsiner and Van der Veer 2000) has become "one of the contemporary authors". But there are many more examples. In the above-mentioned chapter, "The dynamics of child character", Adler's name was deleted various times, as were the names of Lévy-Bruhl, Blondel, and Freud in the second chapter of later editions of Thinking and speech. In volume 3 of the Plenum edition, chapter 3 ends with a footnote in which Vygotsky claims that Watson and Lashley had arrived at similar conclusions as he did. This footnote was missing in previous Soviet editions and was reintroduced by the translator. Finally, a most interesting suppression of a name occurs in that same volume 3. On p. 120, Vygotsky mentions "several of Freud's critics who are inclined to etc." However, it has been discovered that the original text from 1930 ran "several of Freud's critics (such as Voloshinov) who are inclined to etc." This omission is 
theoretically most interesting because Voloshinov belonged to the circle of Bakhtin and theorists have debated the issue as to whether Vygotsky and Bakhtin knew of each other's work.

\section{Unidentified or Suppressed Citations}

Above we already mentioned a lengthy passage from Sapir's Language that was deleted from Vygotsky's Thinking and speech. This was a clear case of a citation that has been removed. It has been claimed that Vygotsky's The Psychology of Art contained several citations from Trotsky that have been removed as well. Other citations in other books have become hard to identify because the quotation marks were removed. We already pointed out the quote from The German Ideology on the final page of Thinking and speech. Etkind (1993) has pointed out that Vygotsky ended his Educational Psychology with a long citation from Trotsky. In effect, this means that the entire last page and part of the previous page of Vygotsky (1997), that is, pp. 350 and 351 from “Alongside technology", were Trotsky's words. Likewise, the final page of "The Crisis" seems to contain a quote from Trotsky. That would mean that the last 4 lines on p. 342 of volume 3 of the Plenum edition are Trotsky's and that the aforementioned reference to a 'superman' was actually Trotsky's (cf. Rieber and Wollock 1997). Recent publications by Zavershneva have confirmed these suspicions (see below).

It is most probable that many more of these hidden citations will be identified in the future. Again, in many cases one can only guess as to the reasons for removing the quotation marks or the citations as a whole. The case of Trotsky is simple, political reasons prohibited mentioning his name or quoting his writings, but other cases are less obvious. One wonders whether editors simply removed quotation marks because they were unable to identify the citations. That would be one way to 'solve' a time-consuming historical problem.

\section{Insertions}

That Soviet or English editors would cut in a historic text is deplorable but to some degree to be expected. That they would go as far as to introduce text fragments ('foreign bodies') into Vygotsky's text seems unlikely. Yet this is precisely what happened on several occasions.

Relatively inoffensive minor insertions can be seen in Vygotsky (1997). The editors or translator have changed, for example, "Lange" into "the Danish psychologist Lange" and "Blonskii" into "Pavel Petrovich Blonskii, the Soviet psychologist and educational reformer". Such insertions are deplorable, not only because they introduce an additional source of error (e.g., Lange was a physiologist and not a psychologist) and confusion (Vygotsky would never have referred to his colleague Blonsky in this way) but also because it becomes impossible to discern where Vygotsky ends and the editor or translator begins. As has been argued elsewhere (Van der Veer 1997), in the restoration of old paintings it has become customary to ensure that any changes are recognizable as such and are reversible. In dealing with historical texts we should follow that principle as well. 
Simply outrageous insertions have been documented for the above-mentioned chapter "The dynamics of child character". This chapter, which was originally published in a 1928 book, not only suffers from numerous suppressions but contains insertions as well. For example, two text fragments from the same 1928 book, but authored by Zalkind, have been inserted into Vygotsky's text. In the Plenum edition these passages run as follows:

Kretschmer's scheme does not work for the division of characterological traits by age. None of this, however, prohibits us from attempting to elucidate the prevailing predominant specific content of each stage in development. This specific content, not now taken into consideration by any of the existing characterological systems, undergoes extraordinary changes under environmental influences. This is why it is dangerous to attach rigid 'labels' to any systems in the given state of science (to be removed from p. 154 of volume 2 of the Plenum edition).

Adler's basic philosophical positions are distorted by metaphysical elements. The characterological interest is limited to Adler's practice (to be removed from p. 156 of volume 2 of the Plenum edition).

These insertions hardly need comment. Apparently, anonymous editors found it necessary to 'clarify' the right position as to Adler's work. That one had to 'enrich' Vygotsky's text to achieve that goal and thus was effectively rewriting history mattered little. The whole process of deleting and inserting passages in psychological texts is reminiscent of the well known Soviet practice of removing persona non grata (e.g Trotsky) from repeatedly published photographs and of the imaginary glorious military past that was invented for several of its rulers.

\section{Programmatic Conclusion: What Needs to Be Done and How?}

The examples given above make for a sad picture: existing English translations based on Soviet re-editions of Vygotsky's work repeat the multiple errors, distortions, falsifications, and omissions these re-editions contained and have introduced errors of their own making.

In our view there is only one remedy and that is to go back to the original sources and to re-translate them. That is, we must gather all the original papers, books, chapters, and manuscripts and publish authoritative translations disregarding the existing Soviet and English translations. However, that is a huge project that commercial publishers would hesitate to undertake. It would involve gathering all of Vygotsky's original publications and manuscripts that are now scattered over different family archives, public libraries, and so on.

In other words, a huge amount of work still remains to be done. The access to the texts and the "archival revolution" in Vygotskian studies is a precondition of any progress in this respect (Yasnitsky 2010a). Fortunately, many new exciting opportunities opened up after the series of recent publications uncovering Vygotsky's private archives (Zavershneva 2007a, b, 2008a, b, 2009b, 2010a, b, c), devoted to textological analysis of Vygotsky's publications (Brushlinsky 1996; Gillen 2000; Mecacci 1990; Peshkov 1999, 2008; Tkachenko 1983; Tulviste 1987; 
Van der Veer 1992, 1997; Zavershneva 2009a; Zavershneva and Osipov 2010), and new, revised, unedited, and, reportedly, undistorted editions of Vygotsky's texts (Vygotskii 1999, 2008). Even more importantly, the miracle of the $21^{\text {st }}$ century, the contemporary technologies of the Internet and the so-called Web 2.0, revolutionized the process of information distribution and scientific publication, and quite a few of the original Vygotsky texts, including the scans of original publications of the interwar period (for instance, the original edition of Thinking and Speech of 1934 and various journal publications of 1920-1930s), are nowadays freely available for downloading from the web. We know about several specialized Russian and international web sites with enormous repositories of information and are confident to claim that this is a rapidly and steadily growing trend in $21^{\text {st }}$ century publishing.

Thus, the reliable translation of Vygotsky's texts and adequate rendering his ideas in English (as well as other languages) seems to be the solution to the problem and answer to the first part of the question we discuss here: What needs to be done?

Yet, the issue of achieving reliability is not as simple as it may look and suggests taking a specific standpoint that several authors referred to as the "cultural-historical approach to cultural-historical psychology". Unfortunately, this proposal not infrequently is not operationalized and remains at the level of mere declarations and wishful thinking. We suggest that such an approach requires the following principles and interpretative practices:

1. Pretty much in accordance with Vygotsky's proposal to consider the origin of psychological functions in the "interpsychological", "intersubjective" domain, as a dialogue and interaction between humans in meaning-making activity, we need to take into account the collaborative and bidirectional nature of Vygotsky's project (Stetsenko 2003; Stetsenko and Arievitch 2004), according to which both Vygotsky's impact on his collaborators and their influences on Vygotsky's theoretical development need to be considered. The traditional-and often criticized (e.g., Luchkov and Pevzner 1981; Orlov 2003) - account of the "troika" (the three) and the "pyaterka" (the five) of Vygotsky's students and close associates (see, e.g., Luria 1979, 1982), has recently been superseded by the study on a Vygotsky Circle of several dozens of Vygotsky's associates and collaborators. This research may reveal the "unknown Vygotsky", "hidden" in the works of his students and conducted in collaboration with him, but published under his students' names (Yasnitsky 2009b; see also Yasnitsky, this issue). A similar discussion of the issues of authorship can be found in the literature concerning the so-called "Bakhtin Circle" (e.g., Shepherd et al. 2003). Recent study and publication of archival materials demonstrate that we can discern several instances of collaborative work done by the group of Vygotsky's associates, which were later published under the name of only one of these collaborators (Yasnitsky 2009a). A classic illustration of the collaborative nature of the Vygotsky Circle project and the controversy about confusing authorship of their written works is the unpublished book chapter on sign and tool that up to date is variously attributed to Vygotsky and Luria (Vygotsky and Luria 1930/1994) and Vygotsky as the sole author (Vygotsky 1930/1999) (for a brief discussion of the issues of authorship, see also Stetsenko 2004). 
2. The cultural-historical approach to Vygotsky's cultural-historical developmental science is hardly conceivable without taking into consideration the development of the Vygotsky project in its entirety, and the interplay between ideas, experimental and social practices. Numerous intellectual biographies of Vygotsky are available; but few of these are really successful in their account of the historical development of Vygotsky's thought. Yet, we argue that most of the historiographical publications about Vygotsky share an essential drawback. Vygotskian literature typically focuses on the ideas of Vygotsky the thinker, and downplays the scientific practices of Vygotsky the experimenter. The studies devoted to Vygotsky's experimentation and interplay between experimental findings and his ideas in the making are rare and, therefore, particularly valuable (see, e.g., Van der Veer 2009). Yet, the exploration of experimental and clinical practices of the Vygotsky project will not only clarify the historical development of ideas and research methods, but will also bring this theory closer to contemporary psychological practice. Clear demonstration of the methodology of Vygotskian experimental research and clinical practice is particularly in demand now that some psychologists - those concerned with the current status of mainstream psychological science described as reductionistic, noncumulative, historically blind, fragmented, and a-theoretical — started asking whether sixty years are gone astray for methodological thinking in psychology (Clegg 2009; Toomela and Valsiner 2010).

3. The cultural-historical approach implies that we view phenomena and processes not as isolated and immanent, but within the rich texture of social and cultural interrelations. With regards to Vygotskian psychology, this means that in order to avoid oversimplifications or misinterpretations we need to take into consideration the broader socio-cultural context of Soviet science of the interwar period. Consider one example.

In a recent publication, Vygotsky's project is quite correctly described as "unique for its practical, political, and civic engagement and ideological commitment to ideals of social justice, equality, and social change", the project that went beyond the narrow confines of psychology in its traditional guise of an ivory-tower elitist enterprise separate from sociocultural transformative practices and instead resulted from, participated in, and contributed to the giant social experiment that at the time took place in Russia (Stetsenko and Arievitch 2004, p. 58). Indeed, the ideas of Vygotsky can hardly be adequately understood unless from the perspective of "transformative practices" they entailed. However, the uniqueness of Vygotsky's project in this respect is grossly overestimated. Thus, a series of recent studies of the "giant social experiment" demonstrate that this sentiment for radical social transformation was characteristic in general for the human sciences in the Soviet Union in the interwar period, specifically, in the fields of criminology and psychology of delinquency, preventive medicine and social hygiene, psychohygiene (i.e. mental hygiene), psychotechnics (i.e., industrial, organizational, and applied psychology and psychophysiology), and paedology (i.e., integrative child sciences) (Beer 2007; Byford 2008; Ewing 2001; Munipov 2006; Pinnow 2010; Sirotkina 2000; Starks 2008; Yasnitsky and Zavershneva 2009). Furthermore, the spirit of social transformation and the betterment of society were clearly not unique for the 
Soviet Union. Thus, for instance, the mental hygiene movement of the 1920-1930s in the United States and Canada demonstrated quite comparable "practical, political, and civic engagement" in the process of the transformation of society, and is said to have had "so deep and pervasive an influence on the theory and practice of American education" that it has "substantially altered our ways of thinking about American education" evidenced by "infiltration of psychiatric norms, concepts and categories of discourse - the 'mental hygiene point of view' - into virtually all aspects of American education in this century, epitomized in the idea of the school's responsibility for children's personality development" (Cohen 1983, p. 124).

Overcoming the narrow confines of the Vygotsky project will certainly help us better assess Vygotsky's innovation and the historical uniqueness of this project's contribution. Yet, the socio-cultural background of the life and work of the Vygotsky Circle is also vital for another reason. It is only within the idiosyncratic local context of scientific research in the Soviet Union that we can potentially properly understand the meaning of this contribution altogether. The idiosyncrasies of science in the Soviet Union of the interwar period are well documented and thoroughly discussed in the rich literature on the history of science in the Soviet Union, and new excellent studies keep coming out. It must be realized that state-sponsored and controlled Soviet science cannot be taken for granted, at face value. There are two main reasons for that. First, scientists in the Soviet Union communicated and regulated their interrelations with their patrons in the party-state apparatus through both frequent direct personal correspondence with the leaders if the state and through a sophisticated system of social practices, rhetoric, and rituals involving such phenomena as "nomadic quotations" from the works of the founders of Marxist teaching and party leaders, the establishment of "founding fathers" in every discipline as another source of quotations and serving the function of the substitutes for the founders of Marxism, the rituals of "public discussions" and election to the "honorary presidiums", celebratory letters addressed "to Comrade Stalin" and other party bosses, the rituals of "self-criticism" in the form of "public confessions" and "repentance", celebration of various "jubilees" and proliferation of the new scholarly genre of "jubilee papers" (Krementsov 1997). Second, another major idiosyncrasy of Soviet science was its discourse and rhetoric devices: a "code" that at times makes it really hard to understand the text and requires special skills of "decoding" the meaning of the message. The revisionist literature on Soviet science demonstrated fairly dramatic shifts from the traditional, Cold War historiography perception of Soviet scientists as "victims" of the oppressive Stalin's regime to the image of "great pretenders" and "tricksters" (Lipovetsky 2009, 2010). According to this view, academic achievement of scholars in the Soviet Union to a considerable extent depended on their success in negotiating their research agendas in the politically correct language of their patrons in power. Therefore, discursive practices of Soviet scientists were largely shaped by the need to merge scientific discourse with propagandist newspeak in pursuit of the support from the Bolshevik leaders of the state and the patrons of science. The resulting discursive hybrid and its peculiar use of vocabulary and stylistic characteristics are at length discussed elsewhere as the "newspeak" of Soviet science (Gerovitch 2002; Krementsov 1997). We even proposed to refer to this discourse as "doublespeak", given that scientists in the Soviet Union followed their agenda that more often than not substantially differed 
from the agenda of party bosses, and employed this discourse in order to manipulate their patrons and fool the party-state system of control over science (Yasnitsky 2009a). Analysis of the rhetorical devices designed to render the double message addressed at the same time to the party-state control apparatus and the scientific community revealed several discursive strategies of peculiar referencing and writing overviews, as well as the techniques that we tentatively termed "quasi-critique" and "shadowboxing" (Yasnitsky 2009b). The research on Soviet scientific discourse is yet another nascent field of investigation, without which, however, we will hardly be able to decode the arcane meaning of a considerable part of the psychological research in the Soviet Union, particularly, in the publications of the late 1930s and from the beginning of the Cold War in the end of the 1940s onwards.

4. Numerous claims of Vygotsky's uniqueness and originality are confronted with an observation that "Vygotsky is credited with 'being 50 years ahead of his time' for ideas that he himself credited to his predecessors of the 1890s and early 1900" (Van der Veer and Valsiner 1991, p. 1). Alternatively, we fully endorse the proposal to consider the "interdependency of ideas" in their historical development that in a most general sense encompasses the four levels of (1) individual knowledge construction by a scholar, (2) interpersonal communications between individuals scholars occupying specific social positions, (3) pursuing their interests in accordance with disciplinary agendas of specific fields of knowledge and branches of science, and, finally, (4) positioned within the framework of a specific society and its multiple institutions (Valsiner and van der Veer 2000). These somewhat general and vaguely defined levels are covered by studies that can be viewed as providing an effective operationalization of the notion of the interdependency of ideas as informal personal networks of scholars, their friends and relatives, domestic and international peers, and the patrons of science (Adams 2001). A series of recent studies demonstrated the power of informal networks of agents as the social embodiment of the interdependency of ideas and practices in the world of Soviet music (Tomoff 2001), cybernetics and computer science (Gerovitch 2002; Tatarchenko 2010), biology and medicine (Krementsov 2005; Solomon 2006), and GermanAmerican psychology (Woodward 2010).

In Soviet psychology, recent studies of scientific communicative practices of the interwar period show that Soviet psychologists had fairly strong ties with their Western peers during Vygotsky's lifetime and were involved in intense scientific exchange as evidenced by their publications in the Soviet Union and abroad and participation in international scientific conferences and congresses (Yasnitsky 2010b, 2011; see also Van der Veer \& Zavershneva, this issue). Furthermore, in certain instances it seems legitimate to view such international communications as transnational research projects involving the networks of scholars from different countries, investigating topics of common interest, and sharing similar research practices. Research on transnational projects involving Soviet psychologists is still in its infancy, yet at least one such project can be discerned. This collaborative project involved the Soviet scholars Lev Vygotsky and Alexander Luria, the GermanAmerican psychologists Kurt Lewin and Kurt Koffka, and their peers, students and associates (Yasnitsky, in press). Further discoveries like this one promise very 
interesting new interpretations of the historical development of psychological theory and important theoretical conceptualizations because, as was recently suggested, "if pre-WWII Continental European psychology would have been studied thoroughly, there would be almost nothing in modern theories that would stand the competition against these early theories" (Toomela and Valsiner 2010, p. 14).

In sum, this is what needs to be done: to get back to the original texts of Vygotsky and the members of his Circle, retranslate and, even more importantly, adequately interpret them from the perspective of the cultural-historical approach to the theory and practice. Overall, we are optimistic, given the contemporary interest in the historical, theoretical and methodological issues of bio-sociocultural psychology and the rapidly developing textological and historiographical research on science. Yet, much work still remains to be done and we truly hope this publication will be of help to those who will undertake this exciting project of - yet again - "understanding Vygotsky".

Open Access This article is distributed under the terms of the Creative Commons Attribution Noncommercial License which permits any noncommercial use, distribution, and reproduction in any medium, provided the original author(s) and source are credited.

\section{References}

Adams, M. B. (2001). Networks in action: The Khrushchev era, the cold war, and the transformation of soviet science. In G. E. Allen \& R. M. MacLeod (Eds.), Science, history, and social activism: A tribute to Everett Mendelsohn (pp. 255-276). Dordrecht: Kluwer Academic.

Beer, D. (2007). Blueprints for change: the human sciences and the coercive transformation of deviants in Russia, 1890-1930. Osiris, 22, 26-47.

Brushlinsky, A. V. (1996). Pervye utochneniya tekstov L.S. Vygotskogo. Psikhologicheskij Zhurnal, 17, 19-25.

Byford, A. (2008). Turning pedagogy into a science: teachers and psychologists in Late Imperial Russia (1897-1917). Osiris, 23, 50-81.

Clegg, J. W. (Ed.). (2009). The observation of human systems. Lessons from the history of antireductionistic empirical psychology. New Brunswick-London: Transaction.

Cohen, S. (1983). The mental hygiene movement, the development of personality and the school: the medicalization of American education. History of Education Quarterly, 23(2), 123-149.

Etkind, A. M. (1993). Eshe o L.S. Vygotskom: Zabytye teksty i nenajdennye konteksty. Voprosy Psikhologii, 38(4), 37-55.

Ewing, E. T. (2001). Restoring teachers to their rights: soviet education and the 1936 denunciation of pedology. History of Education Quarterly, 41(4), 471-493.

Gerovitch, S. (2002). From newspeak to cyberspeak: A history of soviet cybernetics. Cambridge: MIT.

Gillen, J. (2000). Versions of Vygotsky. British Journal of Educational Studies, 48(2), 183-198.

Krementsov, N. L. (1997). Stalinist science. Princeton: Princeton University Press.

Krementsov, N. L. (2005). International science between the world wars: The case of genetics. London: Routledge.

Lipovetsky, M. (2009). Trikster i "zakrytoe" obshchestvo [Trickster and "closed" society]. Novoe literaturnoe obozrenie, 100, 224-245.

Lipovetsky, M. (2010). Charms of cynical reason: Tricksters in Soviet and post-Soviet culture. Academic Studies Press.

Luchkov, V. V., \& Pevzner, M. S. (1981). Znachenie teorii L.S. Vygotskogo dlya psikhologii i defektologii [Contribution of L.S. Vygotsky's theory to psychology and defectology]. Vestnik Moskovskogo universiteta. Seriya 14. Psikhologiya (4), 60-70. 
Luria, A. R. (1979). The making of mind: A personal account of Soviet psychology. Cambridge: Harvard University Press.

Luria, A. R. (1982). Etapy projdennogo puti. Nauchnaya avtobiografiya [The stages of the path passed. Scientific autobiography]. Moscow: MGU.

Mangott, D. (1995). Kontinuität und Wandel im Schaffensprozess von L.S. Vygotskij: Ein russischdeutsches Lexikon zur Ideengeschichte 1926-1934. Mit einer Bibliographie. Innsbruck: Leopold Franzens Universität (Doctoral dissertation).

Mecacci, L. (1990). Edizioni e traduzioni di Pensiero e linguaggio (L. Mecacci, Trans.). In Vygotskij, L. S. Pensiero e Linguaggio. Ricerche psicologiche (pp. xv-xviii). Roma: Laterza.

Munipov, V. M. (2006). I.N. Spielrein, L.S. Vygotskii i S.G. Gellerstein - sozdateli nauchnoj shkoly psikhotekhniki v SSSR [I.N. Spielrein, L.S. Vygotsky and S.G. Gellerstein as founders of scientific school of psychotechnics in the USSR]. Kul'turno-istoricheskaya psikhologiya (2), 85-109.

Orlov, A. B. (2003). A.N. Leont'ev - L.S. Vygotskii: ocherk razvitiya skhizisa [A.N. Leontiev - L.S. Vygotsky: an essay on the development of the schism]. Voprosy psikhologii (2).

Peshkov, I. V. (1999). Tekstologicheskij kommentarij [Textological commentary]. In L. S. Vygotskii, Thinking and speech' (pp. 339). Moscow: Labirint.

Peshkov, I. V. (2008). Tsenzura stilya ne rekomenduetsya [Style censorship is not recommended]. In L. S. Vygotskii (Ed.), Psikhologiya iskusstva (pp. 338-340). Moscow: Labirint.

Pinnow, K. M. (2010). Lost to the collective: Suicide and the promise of soviet socialism, 1921-1929. Ithaca: Cornell University Press.

Rieber, R. W. (Ed.). (1997). The collected works of L.S. Vygotsky. Vol. 4: The history of the development of higher mental functions. New York: Plenum. PE 4.

Rieber, R. W. (Ed.). (1998). The collected works of L.S. Vygotsky. Vol. 5: Child Psychology. New York: Plenum. PE 5.

Rieber, R. W. (Ed.). (1999). The collected works of L.S. Vygotsky. Vol. 6: Scientific legacy. New York: Kluwer Academic/Plenum. PE 6.

Rieber, R. W., \& Carton, A. S. (Eds.). (1987). The collected works of L.S. Vygotsky. Vol. 1: Problems of General Psychology. New York: Plenum. PE 1.

Rieber, R. W., \& Carton, A. S. (Eds.). (1993). The collected works of L.S. Vygotsky. Vol. 2: The fundamentals of defectology. New York: Plenum. PE 2.

Rieber, R. W., \& Wollock, J. (Eds.). (1997). The collected works of L.S. Vygotsky. Vol. 3: Problems of the theory and history of psychology. New York: Plenum. PE 3.

Shepherd, D., Brandist, C., \& Tihanov, G. (Eds.). (2003). The Bakhtin circle: in the master's absence. Manchester: Manchester University Press.

Shif, Zh I. (1935). Razvitie nauchnykh ponyatiy u shkol'nika. Moscow-Leningrad: Gosudarstvennoe Uchebno-Pedagogicheskoe Izdatel'stvo.

Sirotkina, I. E. (2000). Psikhopatologiya i politika: stanovlenie idej i praktiki psikhogigieny v Rossii [Psychopathology and politics: the establishment of the ideas and practice of psychohygiene]. Voprosy istorii estestvoznaniya i tekhniki (1), 154-177.

Solomon, S. G. (2006). Doing medicine together: Germany and Russia between the wars. Toronto: University of Toronto Press.

Starks, T. (2008). The body Soviet: Hygiene, propaganda, and the revolutionary state. Madison: University of Wisconsin Press.

Stetsenko, A. (2003). Alexander Luria and the cultural-historical activity theory: Pieces for the history of an outstanding collaborative project in psychology. Review of E. D. Homskaya (2001), Alexander Romanovich Luria: A scientific biography. Mind, Culture, and Acitivity, 10(1), 93-97.

Stetsenko, A. (2004). Scientific legacy. "Tool and sign in the development of the child". In R. Rieber \& D. Robinson (Eds.), The essential Vygotsky (pp. 501-512). New York: Kluwer Academic/Plenum.

Stetsenko, A., \& Arievitch, I. (2004). Vygotskian collaborative project of social transformation: history, politics, and practice in knowledge construction. The International Journal of Critical Psychology, 12 (4), 58-80.

Tatarchenko, K. (2010). Cold war origins of the international federation for information processing. IEEE Annals of the History of Computing, 32(2), 46-57.

Tkachenko, A. N. (1983). Aktual'nye problemy psikhologii [Actual problems of psychology]. Voprosy psikhologii(1), 156-158.

Tomoff, K. (2001). "Most respected comrade...": patrons, clients, brokers, and unofficial networks in the Stalinist musical world. Contemporary European History, 11(1), 33-65.

Toomela, A., \& Valsiner, J. (Eds.). (2010). Methodological thinking in psychology: 60 years gone astray? Charlotte: Information Age Publishing, Inc. 
Tulviste, P. (1987). Shestitomnoe izdanie trudov L.S. Vygotskogo [Six-volume edition of the works of L. S. Vygotsky]. Voprosy psikhologii (2), 170-173.

Valsiner, J., \& Van der Veer, R. (2000). The social mind. Development of the idea. Cambridge: Cambridge University Press.

Van der Veer, R. (1987). From language and thought to thinking and speech. Review of L.S. Vygotsky, Thought and Language. Journal of Mind and Behavior, 8, 175-177.

Van der Veer, R. (1992). Review of L. S. Vygotsky, Pensiero e linguaggio. Roma: Laterza, 1990. x + 424 p. (cloth). (Annotated Italian translation of the original edition of Thought and Language by Luciano Mecacci). Journal of the History of the Behavioral Sciences, 28(1), 83-84.

Van der Veer, R. (1997). Some major themes in Vygotsky's theoretical work: An introduction. In R. W. Rieber \& J. Wollock (Eds.), The collected works of L.S. Vygotsky. Vol. 3: Problems of the theory and history of psychology (pp. 1-7). New York: Plenum.

Van der Veer, R. (1998). Manuscripts do not burn. Review of L.S. Vygotsky, Educational psychology. Journal of the History of the Behavioral Sciences, 34, 430-431.

Van der Veer, R. (2000). Editor's introduction: Criticizing Vygotsky. Journal of Russian and Eastern European Psychology, 38, 3-9. (appeared in 2002)

Van der Veer, R. (2009). Creating the future: Vygotsky as an experimenter. In J. W. Clegg (Ed.), The observation of human systems. Lessons from the history of anti-reductionistic empirical psychology (pp. 29-43). New Brunswick-London: Transaction.

Van der Veer, R., \& Valsiner, J. (1991). Understanding Vygotsky. A quest for synthesis. Oxford: Blackwell.

Van der Veer, R., \& Valsiner, J. (Eds.). (1994). The Vygotsky reader. Oxford: Blackwell.

Vygodskaya, G. L., \& Lifanova, T. M. (1996). Lev Semenovich Vygotskiy: Zhizn', deyatel'nost', shtrikhi $k$ portretu. Moscow: Smysl.

Vygotskii, L. S. (1999). Thinking and speech' [Thinking and speech]. Moskva: Labirint.

Vygotskii, L. S. (2008). Psikhologiya iskusstva [Psychology of art]. Moskva: Labirint.

Vygotsky, L. S. (1929a). Review of C. and W. Stern, Die Kindersprache. Estvestvoznanie i Marksizm, 3, $185-192$.

Vygotsky, L. S. (1929b). Geneticheskie korni myshlenia i rechi. Estvestvoznanie i Marksizm, 1, $106-133$.

Vygotsky, L. S. (1930/1999). Tool and sign in the development of the child. In R. W. Rieber (Ed.), The collected works of L. S. Vygotsky (Vol. 6. Scientific legacy, pp. 3-68). New York, NY: Plenum Press.

Vygotsky, L.S. (1931). Pedologiya podrostka (pp. 229-289). Moscow-Leningrad: Gosudarstvennoe Uchebno-Pedagogicheskoe Izdatel'stvo.

Vygotsky, L. S. (1932). Foreword. In J. Piaget (Ed.), Rech i myshlenie rebenka (pp. 3-54). MoscowLenigrad: Uchpedgiz.

Vygotsky, L. S. (1962). Thought and language. Cambridge: The MIT.

Vygotsky, L. S. (1971). The psychology of art. Cambridge: The MIT.

Vygotsky, L. S. (1978). Mind in society. Cambridge: Harvard University Press.

Vygotsky, L. S. (1986). Thought and language. Cambridge: The MIT.

Vygotsky, L. S. (1990). Pensiero e linguaggio. Ricerche psicologiche. Roma: Editori Laterza.

Vygotsky, L. S. (1992). Ape, primitive man and child: Essays in the History of Behavior. New York: Harvester Wheatsheaf.

Vygotsky, L. S. (1993). Studies on the history of behavior: Ape, primitive, and child. Hillsdale: Erlbaum. Vygotsky, L. S. (1997). Educational psychology. Boca Raton: St. Lucie.

Vygotsky, L. S., \& Luria, A. R. (1930/1994). Tool and symbol in child development. In R. van der Veer \& J. Valsiner (Eds.), The Vygotsky reader (pp. 99-174). Oxford, UK: Blackwell.

Woodward, W. R. (2010). Russian women émigrées in psychology: informal Jewish networks. History of Psychology, 13(2), 111-137.

Yasnitsky, A. (2009a). Ocherk istorii Khar'kovskoj psikhologicheskoj shkoly: pervaya nauchnaya sessiya Khar'kovskogo gosudarstvennogo instituta i poyavlenie "Khar'kovskoj shkoly psikhologii" (1938) [An outline of the history of the Kharkov school: first scientific session of the Kharkov state pedagogical institute and the emergence of the "Kharkov school of psychology" (1938)]. CulturalHistorical Psychology (2), 95-106.

Yasnitsky, A. (2009b). Vygotsky Circle during the Decade of 1931-1941: Toward an Integrative Science of Mind, Brain, and Education. Ph.D. dissertation, University of Toronto.

Yasnitsky, A. (2010a). Guest editor's introduction: "archival revolution” in Vygotskian Studies? Uncovering Vygotsky’s archives. Journal of Russian and East European Psychology, 49(1), 3-13.

Yasnitsky, A. (2010b). Ob izolyatsionizme sovetskoj psikhologii: zarubezhnye konferentsii 1920-30-kh gg. [Regarding the isolationism of Soviet psychology: International conferences in the 1920-1930s]. Voprosy psikhologii (3), 101-112. 
Yasnitsky, A. (2011). Ob izolyatsionizme sovetskoj psikhologii: nauchnye publikatsii 1920-30-kh gg. [Regarding the isolationism of Soviet psychology: scientific publications in the 1920-1930s]. Voprosy psikhologii (1).

Yasnitsky, A., \& Zavershneva, E. (2009). Ob arkhetipe sovetskoj psikhologii kak nauchnoj distsipliny i sotsial'noj praktiki [On the archetype or Soviet psychology as scientific discipline and social practice]. Novoe literaturnoe obozrenie, 100, 334-355.

Zavershneva, E. (2007a). K publikatsii zametok L.S. Vygotskogo [To the publication of L.S. Vygotsky's notes]. Metodologiya i istoriya psikhologii, 2(4), 15-24.

Zavershneva, E. (2007b). "Put' k svobode" (K publikatsii materialov iz semejnogo arkhiva L.S. Vygotskogo) ["The road to freedom" (To the publication of the materials from the family archive of L. S. Vygotsky)]. Novoe literaturnoe obozrenie, 85 .

Zavershneva, E. (2008a). Zapisnye knizhki, zametki, nauchnye dnevniki L.S. Vygotskogo: rezul'taty issledovaniya semejnogo arkhiva [Notebooks, notes, scientific diaries of L.S. Vygotsky: the results of the investigation of the family archive, part 1]. Voprosy psikhologii (1), 132-145.

Zavershneva, E. (2008b). Zapisnye knizhki, zametki, nauchnye dnevniki L.S. Vygotskogo: rezul'taty issledovaniya semejnogo arkhiva [Notebooks, notes, scientific diaries of L.S. Vygotsky: the results of the investigation of the family archive, part 2]. Voprosy psikhologii (2), 120-136.

Zavershneva, E. (2009a). Issledovanie rukopisi L.S. Vygotskogo "Istoricheskij smysl psikhologicheskogo krizisa" [An investigation of the manuscript of L.S. Vygotsky's "Historical meaning of psychological crisis"]. Voprosy psikhologii (6), 119-137.

Zavershneva, E. (2009b). "Klyuch k psikhologii cheloveka": kommentarii k bloknotu L.S. Vygotskogo iz bol'nitsy "Zakhar'ino" (1926) ["Key to human psychology": Commentaries to L.S. Vygotsky's notebook written in Zakhar'ino hospital (1926)]. Voprosy psikhologii (3), 123-141.

Zavershneva, E. (2010a). The Vygotsky family archive (1912-1934). New findings. Journal of the Russian and East European Psychology, 48(1), 14-33.

Zavershneva, E. (2010b). The Vygotsky family archive: new findings. Notebooks, Notes, and Scientific Journals of L.S. Vygotsky (1912-1934). Journal of the Russian and East European Psychology, 48 (1), 34-60.

Zavershneva, E. (2010c). "The way to freedom" (On the Publication of Documents from the Family Archive of Lev Vygotsky). Journal of the Russian and East European Psychology, 48(1), 61-90.

Zavershneva, E., \& Osipov, M. E. (2010). Osnovnye popravki k tekstu "Istoricheskij smysl psikhologicheskogo krizisa", opublikovannomu v sobranii sochinenij L.S. Vygotskogo (1982-1984) [Main corrections to the text of "Historical meaning of psychological crisis" published in the collected works of L.S. Vygotsky (1982-1984)]. Voprosy psikhologii (1), 92-102.

René van der Veer is Casimir professor of the history of education at Leiden University, The Netherlands. He published widely on the history of developmental psychology and pediatrics. Among his books are Understanding Vygotsky (with Valsiner, 1991), The Social Mind (with Valsiner, 2000), Lev Vygotsky (2007), and Opvoeden door Beginners (2011).

Anton Yasnitsky ( $\mathrm{PhD}$ from University of Toronto, 2009) is a SSHRC Postdoctoral Fellow at York University and University of Toronto. He is primarily interested in the history, theory and methodology of psychology, specifically, post-Vygotskian psychology (cultural-historical theory and activity-oriented psychology). He has published a series of research articles on the so-called Kharkov School of Vygotsky's students and the problems of isolationism of Soviet and Russian psychology (in English and Russian). Among his other interests are modern-day applications of Vygotskian theory in developmental psychological and educational research. Most recently he has edited a number of special issues of the Journal of Russian and East European Psychology and the Russian-language journal Kul'turnoistoricheskaia psikhologiia [Cultural-historical Psychology] on Soviet and East European psychology of memory in the context of contemporary international psychology and a special issue on the "Archival revolution" in Vygotskian studies featuring Ekaterina Zaversneva's groundbreaking research in Vygotsky's archives. His numerous research interests surface in his work on The Cambridge Handbook of CulturalHistorical Psychology (co-edited with R. van der Veer and M. Ferrari) scheduled to come out in 2012. 